\title{
Repeat hydrography in the Mediterranean Sea, data from the Meteor cruise 84/3 in 2011
}

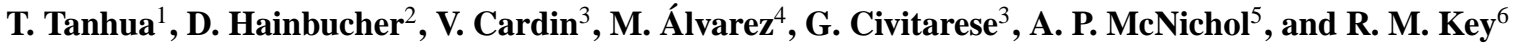 \\ ${ }^{1}$ GEOMAR Helmholtz Centre for Ocean Research Kiel, Department of Chemical Oceanography, \\ Düsternbrooker Weg 20, 24105 Kiel, Germany \\ ${ }^{2}$ ZMAW, Institut für Meereskunde, University of Hamburg, Bundesstraße 53, 20146 Hamburg, Germany \\ ${ }^{3}$ Istituto Nazionale di Oceanografia e di Geofisica Sperimentale - OGS, Dept. of Oceanography, \\ Borgo Grotta Gigante 42/c, 34010 Sgonico, Trieste, Italy \\ ${ }^{4}$ IEO, Instituto Español de Oceanografía, Centro de A Coruña, Apdo. 130, 15001 A Coruña, Spain \\ ${ }^{5}$ NOSAMS, Woods Hole Oceanographic Institute, Woods Hole, MA, USA \\ ${ }^{6}$ Atmospheric and Oceanic Sciences Program, Princeton University, Princeton, NJ, USA \\ Correspondence to: T. Tanhua (ttanhua@geomar.de)
}

Received: 5 March 2013 - Published in Earth Syst. Sci. Data Discuss.: 18 March 2013

Revised: 3 July 2013 - Accepted: 7 July 2013 - Published: 31 July 2013

\begin{abstract}
Here we report on data from an oceanographic cruise on the German research vessel Meteor covering large parts of the Mediterranean Sea during spring of 2011. The main objective of this cruise was to conduct measurements of physical, chemical and biological variables on a section across the Mediterranean Sea with the goal of producing a synoptic picture of the distribution of relevant physical and biogeochemical properties, in order to compare those to historic data sets. During the cruise, a comprehensive data set of relevant variables following the guide lines for repeat hydrography outlined by the GO-SHIP group (http://www.go-ship.org/) was collected. The measurements include salinity and temperature (CTD), an over-determined carbonate system, inorganic nutrients, oxygen, transient tracers $\left(\mathrm{CFC}-12, \mathrm{SF}_{6}\right)$, helium isotopes and tritium, and carbon isotopes. The cruise sampled all major basins of the Mediterranean Sea following roughly an east-to-west section from the coast of Lebanon through to the Strait of Gibraltar, and to the coast of Portugal. Also a southto-north section from the Ionian Sea to the Adriatic Sea was carried out. Additionally, sampling in the Aegean, Adriatic and Tyrrhenian Seas were carried out. The sections roughly followed lines and positions that have been sampled previously during other programs, thus providing the opportunity for comparative investigations of the temporal development of various parameters.
\end{abstract}

\section{Data coverage and parameters measured}

Repository-Reference:

doi:10.3334/CDIAC/OTG.CLIVAR_06MT20110405

Available at: Bottle data:

http://cdiac.ornl.gov/oceans/Coastal/Meteor_Med_Sea.html

CTD continuous profiles:

http://cchdo.ucsd.edu/cruise/06MT20110405

Coverage: $33-42^{\circ} \mathrm{N} ; 36^{\circ} \mathrm{E}-8^{\circ} \mathrm{W}$

Location Name: The Mediterranean Sea

Date/Time Start: 5 April 2011

Date/Time End: 28 April 2011

\section{Introduction}

The Mediterranean Sea is a relatively small, land-locked ocean basin with an active deep and shallow overturning and complex upper layer circulation. The last few decades has seen dramatic changes in the circulation of the Mediterranean Sea. This is manifested, amongst others, as a shift of the deep water formation area from the Adriatic to the Aegean Sea in the Eastern Mediterranean Sea, and an intense deep water formation event in the mid-2000s in the Western Mediterranean Sea (e.g. Roether et al., 1996; Schroeder et al., 2008). The deep water formed from these two sources 
Table 1. List of variables available from the Meteor cruise M84/3 in 2011. The PIs listed in the last column are: (1) Dagmar Hainbucher, (2) Marta Alvarez, (3) Toste Tanhua, (4) Robert Key, Princeton University, NJ, USA and Ann McNichol, WHOI, USA.

\begin{tabular}{|c|c|c|c|c|c|}
\hline Parameter & Short name & Unit & Flag name & Comment & $\mathrm{PI}^{*}$ \\
\hline Latitude & LATITUDE & ${ }^{\circ} \mathrm{N}$ & & & \\
\hline Longitude & LONGITUDE & ${ }^{\circ} \mathrm{E}$ & & & \\
\hline Pressure & CTDPRS & dbar & & & 1 \\
\hline Temperature & CTDTMP & ${ }^{\circ} \mathrm{C}$ & & in situ temperature ITS-90 & 1 \\
\hline Salinity & CTDSAL & & CTDSAL_FLAG_W & PSS-78 & 1 \\
\hline Oxygen & CTDOXY & $\mu \mathrm{mol} \mathrm{kg}{ }^{-1}$ & CTDOXY_FLAG_W & From the CTD probe & 1 \\
\hline Oxygen & OXYGEN & $\mu \mathrm{mol} \mathrm{kg}{ }^{-1}$ & OXYGEN_FLAG_W & From winkler titration & 2 \\
\hline Silicate & SILCAT & $\mu \mathrm{mol} \mathrm{kg}-1$ & SILCAT_FLAG_W & & 3 \\
\hline Nitrate & NITRAT & $\mu \mathrm{mol} \mathrm{kg} \mathrm{kg}^{-1}$ & NITRAT_FLAG_W & & 3 \\
\hline Nitrite & NITRIT & $\mu \mathrm{mol} \mathrm{kg}{ }^{-1}$ & NITRIT_FLAG_W & & 3 \\
\hline Phosphate & PHSPHT & $\mu \mathrm{mol} \mathrm{kg} \mathrm{kg}^{-1}$ & PHSPHT_FLAG_W & & 3 \\
\hline CFC-12 & CFC-12 & pmol kg-1 & CFC-12_FLAG_W & & 3 \\
\hline $\mathrm{SF}_{6}$ & SF6 & fmol kg-1 & SF6_FLAG_W & & 3 \\
\hline Dissoled Inorganic Carbon & TCARBN & $\mu \mathrm{mol} \mathrm{kg} \mathrm{kg}^{-1}$ & TCARBN_FLAG_W & & 2 \\
\hline Total Alkalinity & ALKALI & $\mu \mathrm{mol} \mathrm{kg}{ }^{-1}$ & ALKALI_FLAG_W & & 2 \\
\hline $\mathrm{pH}$ & PH_TOT & & PH_TOT_FLAG_W & total scale at $25^{\circ} \mathrm{C}$ & 2 \\
\hline Tritium $\left({ }^{3} \mathrm{H}\right)$ & TRITTUM & Tritium Units (TU) & TRITTUM_FLAG_W & & 3 \\
\hline Uncertainty of tritium data & TRITER & Tritium Units (TU) & & & 3 \\
\hline Helium & HELIUM & $\mathrm{nmol} \mathrm{kg} \mathrm{kg}^{-1}$ & HELIUM_FLAG_W & & 3 \\
\hline$\delta^{3} \mathrm{He}$ & DELHE3 & $\%$ & DELHE3_FLAG_W & & 3 \\
\hline Uncertainty of $\delta^{3} \mathrm{He}$ data & DELHER & $\%$ & & & 3 \\
\hline Neon & NEON & $\mathrm{nmol} \mathrm{kg} \mathrm{kg}^{-1}$ & NEON_FLAG_W & & 3 \\
\hline$\Delta^{14} \mathrm{C}$ & DELC14 & Per mille & DELC14_FLAG_WW & & 4 \\
\hline Uncertainty of $\Delta^{14} \mathrm{C}$ data & C14ERR & Per mille & & & 4 \\
\hline$\delta^{13} \mathrm{C}$ & DELC13 & Per mille & DELC13_FLAG_W & & 4 \\
\hline
\end{tabular}

* The shipboard personnel for these measurements are mentioned in the cruise report.

has different properties of salinity and temperature and different biogeochemical signature. The Mediterranean Sea is obviously not in steady state and is potentially sensitive to climatic changes. The characteristic of the Mediterranean Sea is further such that it has the potential to sequester large amounts of anthropogenic $\mathrm{CO}_{2}, \mathrm{C}_{\mathrm{ant}}$, i.e. the Mediterranean Sea has high alkalinity and temperature, which can rapidly be transported to depth by the overturning circulation (e.g. Schneider et al., 2010). The column inventories of $\mathrm{C}_{\mathrm{ant}}$ in the Mediterranean is among the highest found anywhere in the world oceans; the Mediterranean Sea thus stores a significant portion of the global anthropogenic emissions of $\mathrm{CO}_{2}$ despite its relatively small volume. However, few inorganic carbon data exist in the Mediterranean Sea, and knowledge about how recent changes in circulation are affecting the storage rate of $\mathrm{C}_{\mathrm{ant}}$ is fundamental.

Here we report on a data set obtained during spring 2011 on the German research vessel Meteor, cruise M84/3 (EXPOCODE: 06MT20110405). The cruise was set-up to follow the demands and requirements of repeat hydrography as specified by the GO-SHIP group (http://www.go-ship.org/), i.e. with a comprehensive set of physical and chemical parameters measured to the highest standards. The principal scientific objectives for M84/3 had two closely linked components: understanding and documenting the large-scale Mediterranean water property distributions, their changes and the drivers of those changes. These data will support understanding and addressing questions of a future Mediterranean Sea that will experience increasing concentrations of dissolved inorganic carbon, might become more stratified and experience changes in circulation and ventilation processes. These objectives were achieved by measurements of physical parameters with CTD (including oxygen) and by on-board measurements of discrete water samples for oxygen, nutrients (nitrate, nitrite, phosphate and silicate), dissolved inorganic carbon (DIC), total alkalinity, $\mathrm{pH}$, and the transient tracers $\mathrm{SF}_{6}$ and $\mathrm{CFC}-12$. In addition, samples were taken for the determination of ${ }^{3} \mathrm{He}$ and tritium, as well as for the carbon isotopes ${ }^{14} \mathrm{C}$ and ${ }^{13} \mathrm{C}$, for later shore-based analyses. Here we present a short description of the M84/3 cruise that started in Istanbul (Turkey) on 4 April and ended in Vigo (Spain) on 28 April 2011. The cruise track is shown in Fig. 1. For a sub-set of the CTD stations, no chemistry was performed due to time limitations, and for another subset of stations a comprehensive tracer program with sampling for helium (including tritium) and carbon isotopes were performed; these sub-sets are marked with different colors in Fig. 1. A more comprehensive report from the observing 
program during cruise $\mathrm{M} 84 / 3$ can be found in the cruise report (Tanhua, 2013).

\section{Instrumentation}

\subsection{CTD}

Altogether, 61 standard hydrographic stations were occupied during the cruise, employing a SeaBird SBE911 plus CTD$\mathrm{O}_{2}$ probe, attached to a SeaBird carousel 24 bottle watersampler. At most stations water samples were taken from 24 depth levels within the water column from the surface to the bottom. At least three of those were analyzed for salinity onboard using certified reference seawater $38 \mathrm{H} 11$ with a K15factor of $1.07631\left(24^{\circ} \mathrm{C}\right)$. The CTD data were post-processed by applying Seabird software and MATLAB routines. At this stage, spikes were removed, $1 \mathrm{dbar}$ average calculated, and temperature, salinity and oxygen were corrected with a regression analysis which fits the downcast profiles with the temperature and salinity. Since corrections to these parameters were small, the data quality was excellent. Overall accuracies are within expected ranges: $0.002{ }^{\circ} \mathrm{C}$ for temperature, 0.003 for salinity and approximately $2 \mu \mathrm{mol} \mathrm{kg}{ }^{-1}$ for oxygen.

Samples for chemical analysis of discrete water samples were drawn from $10 \mathrm{~L}$ Niskin bottles. The sampling order were always: helium, $\mathrm{CFC} 12 / \mathrm{SF}_{6}$, oxygen, DIC/Carbon isotopes, $\mathrm{pH}$, alkalinity, nutrients, tritium, salinity and other samples. Below follows a short description of the various onboard measurements.

\subsection{Dissolved oxygen}

Dissolved oxygen was measured at all chemistry stations for all depths following the Winkler potentiometric method modified after Langdon (2010). Two independent reference materials for the iodate standard were used to calibrate the thiosulfate solution: commercial potassium iodate solutions of $0.01 \mathrm{~N}\left(20^{\circ} \mathrm{C}\right)$ provided by OSIL (UK) and Wako (Japan). Three reproducibility exercises were performed along the cruise, resulting in an estimated precision of $\pm 0.6 \mu \mathrm{mol} \mathrm{kg}-1$ or better.

\subsection{The carbonate system}

All the stations and depths were sampled for total alkalinity (TA), dissolved inorganic carbon (DIC) and $\mathrm{pH}$, in order to have an over-determined $\mathrm{CO}_{2}$ system. The DIC content was determined using a SOMMA instrument. Samples were collected in borosilicate bottles according to standard operation protocol. A small headspace $(<1 \%)$ was adjusted to prevent pressure build-up and loss of $\mathrm{CO}_{2}$ during storage. Samples were not poisoned and normally measured within $12 \mathrm{~h}$; the samples were kept at $20( \pm 0.2)^{\circ} \mathrm{C}$ during the analysis. An aliquot of approximately $26 \mathrm{~mL}$ was transferred to the instrument where it was acidified with phosphoric acid and the outgassed $\mathrm{CO}_{2}$ was measured coulometrically. The precision of the analysis was determined to $\pm 0.6 \mu \mathrm{mol} \mathrm{kg}{ }^{-1}$ by titration of several bottles filled from the same Niskin bottles. The accuracy was determined to be $2.5 \mu \mathrm{mol} \mathrm{kg}{ }^{-1}$ by analyzing a total of 42 bottles of certified reference material (CRM, Andrew Dickson, Scripps, CA, USA, batch 108); the DIC of this batch is certified at $2022.70 \pm 0.7 \mu \mathrm{mol} \mathrm{kg}{ }^{-1}$. Measurements of the CRMs were also used to daily correct the temporal drift in the coulometer cell; this correction was never larger than $3 \mu \mathrm{mol} \mathrm{kg} \mathrm{kg}^{-1}$.

Spectrophotometric $\mathrm{pH}$ in seawater was measured at every station and depth using a double-wavelength spectrophotometric procedure (Clayton and Byrne, 1993), and is reported at $25^{\circ} \mathrm{C}$ and on the total scale; i.e. pH25T. Samples were collected in cylindrical optical glass $10 \mathrm{~cm}$ path-length cells, which were filled to overflowing and immediately closed. All the absorbance measurements were obtained in the thermostated cell at $25 \pm 0.2^{\circ} \mathrm{C}$. The absorbance was measured at three different fixed wavelengths $(434,578$ and $730 \mathrm{~nm})$ and calculated using the formula in Clayton and Byrne (1993). A correction was applied to compensate for the injection of the indicator into the seawater. The magnitude of this correction over our range of $\mathrm{pH}$ is small, ranging from 0.003 to $0.0007 \mathrm{pH}$ units. The accuracy of the $\mathrm{pH}$ measurements were determined by analyzing ten to fifteen samples per week of $\mathrm{CO}_{2}$ reference material (CRM, batch 108). Since the $\mathrm{pH}$ in these CRMs are not given, the $\mathrm{pH}$ of this batch was calculated to 7.8782 using the dissociation constants from Mehrbach et al. (1973) refitted by Dickson and Millero (1987). Our pH measurements on the CRMs were lower than this theoretical value but according to an internal consistency analysis detailed in Álvarez et al. (2013) no correction was applied. On three occasions several samples collected from the same Niskin bottle were analyzed, giving the reproducibility of the $\mathrm{pH}$ measurements to be 0.0012 units.

Samples for total alkalinity (TA) determination were collected in $600 \mathrm{~mL}$ borosilicate bottles and were analyzed within a day after sampling. The TA samples were analyzed following a double end point potentiometric technique by Pérez and Fraga (1987) and Pérez et al. (2000). Measurements of CRM were performed in order to control the accuracy of the TA measurements; the $\mathrm{pH}$ as measured by the electrode was corrected to obtain the closest mean TA to the $\mathrm{CRM}$; the $\mathrm{pH}$ correction was never larger than 0.05 . The precision of the TA measurements was better than $0.6 \mu \mathrm{mol} \mathrm{kg}{ }^{-1}$ determined from duplicate Niskin bottles, and the accuracy of the TA measurements (i.e. including sampling errors) is determined to be $1 \mu \mathrm{mol} \mathrm{kg}{ }^{-1}$ using CRMs measurements. Additionally, the daily drift of the system was determined by regular measurements of a substandard (aged surface seawater); this drift was always very low. Substandards of aged surface seawater were used instead of CRMs in order to minimize use of expensive CRMs; several tests confirmed that this procedure produces as accurate results as using CRMs. 


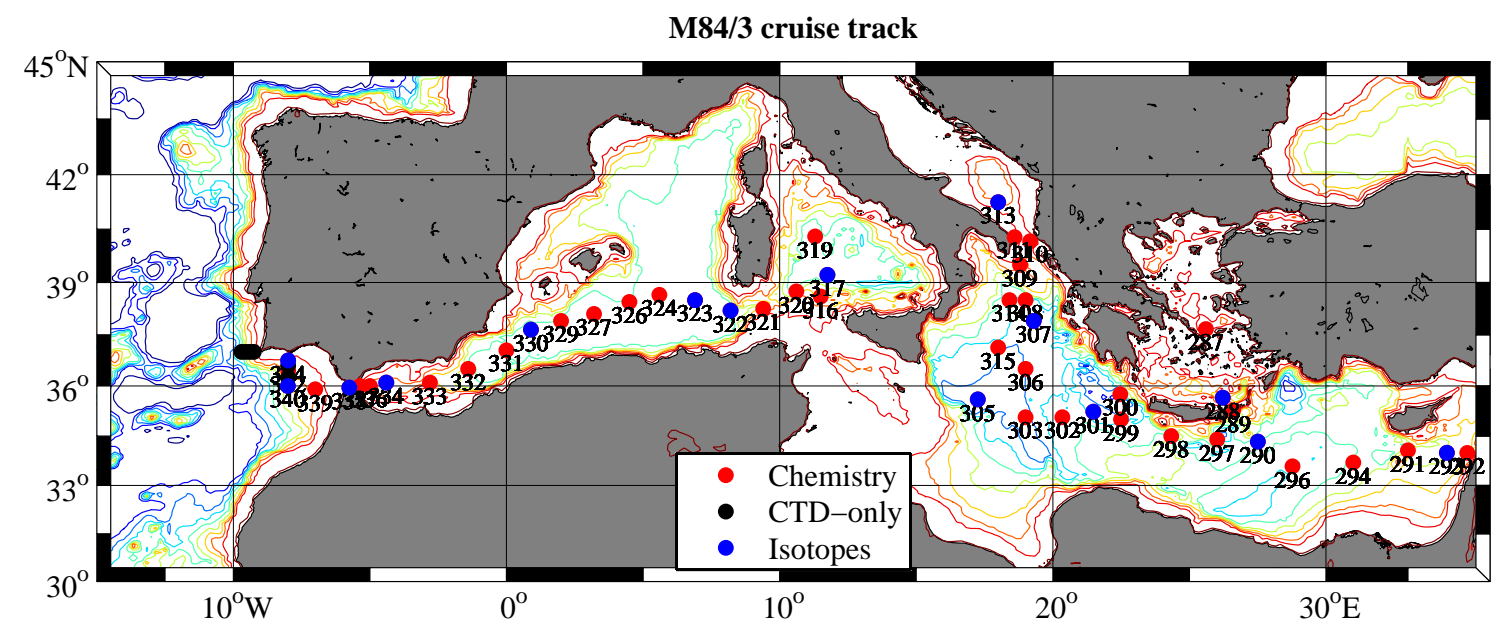

Figure 1. Cruise track of M84/3 with CTD stations marked in different colors based on the extent of measurements carried out.

The $\mathrm{CO}_{2}$ system was over-determined during the cruise by simultaneous measurements of DIC, TA and $\mathrm{pH}$. This allowed us to perform an internal consistency analysis of the data. We used (Mehrbach et al., 1973) refit by (Dickson and Millero, 1987) constants to calculate DIC from measured of $\mathrm{pH} 25 \mathrm{~T}$ and TA, which yields an error of about $4 \mu \mathrm{mol} \mathrm{kg} \mathrm{kg}^{-1}$. TA calculated from measured $\mathrm{pH} 25 \mathrm{~T}$ and DIC yields an error of about $3 \mu \mathrm{mol} \mathrm{kg} \mathrm{kg}^{-1}$. $\mathrm{pH} 25 \mathrm{~T}$ calculated from measured TA and DIC yields an error of about $0.003 \mu \mathrm{mol} \mathrm{kg}{ }^{-1}$. Figures and additional information on the internal consistency of the carbonate system can be found in the cruise report (Tanhua, 2013) and the work by Álvarez et al. (2013).

\section{$2.4 \mathrm{SF}_{6}$ and $\mathrm{CFC}-12$}

During the cruise, two gas chromatograph/purge-and-trap (GC/PT) systems (PT2 and PT3) were used for the measurements of the transient tracers $\mathrm{CFC}-12$ and $\mathrm{SF}_{6}$, similar to the set-up described by Bullister and Wisegarver (2008). For PT3, samples were collected in $250 \mathrm{~mL}$ ground glass syringes, and an aliquot of about $200 \mathrm{~mL}$ was injected into the analytical system. For PT2, samples were collected in $350 \mathrm{~mL}$ glass ampoules, and an aliquot of about $250 \mathrm{~mL}$ was injected into the system through a vacuum-sparge technique, similar to that described by Law et al. (1994). Measurements for the first half of the cruise were conducted on instrument "PT2", and later, due to a defect Electron Capture Detector (ECD), conducted on instrument "PT3". During the transition between the instruments, samples were flame-sealed in $~ 350 \mathrm{~mL}$ ampoules. The system "PT3" was not able to measure $\mathrm{SF}_{6}$, so that only CFC-12 could be measured on board. However, samples from selected stations in the Western Mediterranean Sea were flame-sealed for the measurement of $\mathrm{SF}_{6}$; all flame-sealed ampoules were measured onshore at the lab at IFM-GEOMAR in Kiel after the cruise. The CFC-12 data are reported on the SIO98 scale and $\mathrm{SF}_{6}$ on the NOAA-2000 scale. Calibration curves were measured every few days to characterize the non-linearity of the system, and point calibrations were performed regularly to determine the short-term drift in the detector. Replicate measurements were taken on a few stations and the reproducibility was determined to be $1.0 \% / 0.65 \%$ for CFC- $12 / \mathrm{SF}_{6}$ measurements on PT2, and $0.34 \%$ for CFC-12 measured on PT3, whereas the values are approximately twice as large for the offline measurements of flame-sealed ampoules. A detailed account for the CFC-12 and $\mathrm{SF}_{6}$ measurements can be found in Stöven (2011).

\subsection{Nutrients}

Nutrients (nitrate, nitrite, silicate, and phosphate) were measured on-board with a Quaatro auto-analyzer from SEAL analytics. The following protocols from SEAL analytics were followed: Nitrite and Nitrate - Method No Q-068-05 Rev. 4; Phosphate - Method No Q-031-04 Rev. 2; Silicate - Method No Q-066-05 Rev. 3. The reproducibility of the nutrient measurements, as $\mathrm{C}_{v} \%$, were determined to Nitrite $+\mathrm{Ni}$ trate: $\leq 1.5 \%$; Phosphate: $\leq 3.6 \%$; Silicate: $\leq 1.7 \%$, or if expressed as in $\mu \mathrm{mol} \mathrm{kg}{ }^{-1}$ : Nitrate 0.08; Phosphate 0.007; Silicate 0.10 , based on measurements of replicate samples.

\subsection{Helium and tritium}

During the cruise, samples for helium isotope were taken for measurements by two different groups: samples were taken at 10 stations along the whole depth profile for measurement of ${ }^{3} \mathrm{He}$ and tritium at Institute of Environmental Physics at the University of Bremen, Germany. At 13 other stations, samples were taken for the analysis of ${ }^{3} \mathrm{He}$ at the Laboratoire de Sciences du Climat in LSCE-CEA, Saclay, France. The volume of the helium samples were either 40 or $6.4 \mathrm{~mL}$ for the two groups, respectively, and sampled in copper tubes. Samples for tritium analysis were taken in $1 \mathrm{~L}$ plastic bottles and 
stored into zip-locked plastic bags. At station 301, a brine lake was sampled that contained very high concentrations of radiogenic helium, which lead to contamination of the Niskin bottles so that values for ${ }^{3} \mathrm{He}$ had to be flagged as questionable for stations 301, 303 and 305 .

\subsection{Carbon isotopes}

Samples were collected for post-cruise measurement of carbon isotopes in the dissolved inorganic carbon. A total of 256 results were reported for ${ }^{13} \mathrm{C}$ and 263 for ${ }^{14} \mathrm{C}$. After rinsing, the samples were collected in $500 \mathrm{ml}$ bottles, immediately poisoned with $100 \mu \mathrm{L}$ saturated $\mathrm{HgCl}_{2}$, then sealed according to standard procedures (NOSAMS protocol). The samples were shipped to the National Ocean Sciences AMS Facility at Woods Hole Oceanographic Institution, USA; http://www.whoi.edu/nosams/home. The propagated counting and background uncertainty of the $\Delta^{14} \mathrm{C}$ analyses averaged about $0.5 \%$, but the total uncertainty based on replicate analyses is about $3.5 \%$ (Elder et al., 1998). This data set represents the first large-scale survey of the carbon-isotope measurements in the Mediterranean Sea.

\subsection{Auxiliary data}

Several additional and complementary measurement and sampling programs were carried out during the cruise, although the data are currently not available in the data repository at CDIAC due to long processing times. These measurements include: surface distribution of persistent organic pollutants, measurements of Polyfluorooctansulfonate, dissolved barium, large volume sample collections for the determination of Ra isotopes, determination of microbiological community structure (Mapelli et al., 2013), determination of the isotopic composition, abundance and size of coccolithophores, aerosol sampling with daily resolution, incubation experiments for nitrogen fixation (Rahav et al., 2013), determination of methyl-mercury, and determination of neodymium isotopes. Information on access to these data can be found at CDIAC; http://cdiac.ornl.gov/oceans/ Coastal/Meteor_Med_Sea.html.

\section{Dataset}

The data set from Meteor cruise M84/3 is composed of two main components; the continuous profiles from the CTD, and the discrete data from the water samples. The data set contains information from 61 hydrographic stations. Of these, 47 were CTD-cast with chemistry samples, 6 stations were devoted to large volume sampling of Radium isotopes, and 8 stations were only for CTD measurements.

The CTD data are reported as $1 \mathrm{dbar}$ for temperature, salinity and oxygen.

The bottle data are reported in standard World Hydrographic Program (WHP) Exchange format (Swift, 2008).
This format is commonly used for reporting of bottle data, and is the format used by CDIAC and CCHDO, for instance.

\section{Data access}

The hydrographic data set is published at two different repositories due to the different scope of the repositories. The bottle data is available at the Carbon Dioxide Information Analysis Center (CDIAC), Oak Ridge, TN, USA, (Tanhua et al., 2012); http://cdiac.ornl.gov/oceans/Coastal/Meteor_ Med_Sea.html.

The CTD profile data are available at the CLIVAR and Carbon Hydrographic Data Office (CCHDO), UCSD Scripps Institution of Oceanography, San Diego, CA, USA; http:// cchdo.ucsd.edu/cruise/06MT20110405.

Acknowledgements. We would like to thank captain Thomas Wunderlich, his officers and crew of RV Meteor for their support of our measurement program and for creating a very friendly and professional work atmosphere on board. The ship time of Meteor was provided by the German Science Foundation (DFG) within the core program METEOR/MERIAN. Significant support for the cruise was provided by the Senatskommision für Ozeanographie der DFG through the "Koordinatorantrag M84". The participation of G. Civitarese and V. Cardin on the M84/3 cruise was supported by the Mediterranean Science Commission (CIESM). The measurements of carbon isotopes was funded by a grant from the collaborative research project "Collection and Analysis of Radiocarbon Samples on Repeat Hydrography Lines", NSF OCE-0825163.

Edited by: F. Schmitt

Reviewed by: K. Schroeder and one anonymous referee

\section{References}

Álvarez, M., Sanleón-Bartolomé, H., Tanhua, T., Mintrop, L., Luchetta, A., Cantoni, C., Schroeder, K., and Civitarese, G.: The $\mathrm{CO}_{2}$ system in the Mediterranean Sea, a basin wide perspective, in preparation, 2013.

Bullister, J. L. and Wisegarver, D. P.: The shipboard analysis of trace levels of sulfur hexafluoride, chlorofluorocarbon-11 and chlorofluorocarbon-12 in seawater, Deep-Sea Res. Pt. I, 55, 1063-1074, 2008.

Clayton, T. D. and Byrne, R. H.: Spectrophotometric seawater $\mathrm{pH}$ measurements: total hydrogen ion concentration scale concentration scale calibration of m-cresol purple and at-sea results, DeepSea Res. Pt. I, 40, 2115-2129, 1993.

Dickson, A. G. and Millero, F. J.: A comparison of the equilibrium constants for the dissociation of carbonic acid in seawater media, Deep-Sea Res., 34A, 1733-1743, 1987.

Elder, K. L., McNichol, A. P., and Gagnon, A. R.: Reproducibility of seawater, inorganic and organic carbon $14 \mathrm{C}$ results at NOSAMS, Radiocarbon, 40, 223-230, 1998.

Langdon, C.: Determination of dissolved oxygen in seawater by winkler titration using the amperometric technique, IOCCP Report No. 14, ICPO publication series N 134, 2010. 
Law, C. S., Watson, A. J., and Liddicoat, M. I.: Automated vacuum analysis of sulphur hexafluoride in seawater: Derivation of the atmospheric trend (1970-1993) and potential as a transient tracer, Mar. Chem., 48, 57-69, 1994.

Mapelli, F., Varela, M. M., Barbato, M., Alvariño, R., Fusi, M., Álvarez, M., Merlino, G., Daffonchio, D., and Borin, S.: Biogeography of planktonic bacterial communities across the whole Mediterranean Sea, Ocean Sci., 9, 585-595, doi:10.5194/os-9585-2013, 2013.

Mehrbach, C., Culberson, C. H., Hawley, J. E., and Pytkowitcz, R. M.: Measurements of the apparent dissociation constants of carbonic acid in seawater at atmospheric pressure., Limnol. Oceanogr., 18, 897-907, 1973.

Pérez, F. F. and Fraga, F.: A precise and rapid analytical procedure for alkalinity determination, Mar. Chem., 21, 169-182, 1987.

Pérez, F. F., Ríos, A. F., Rellán, T., and Álvarez, M.: Improvements in a fast potentiometric seawater alkalinity determination, Cienc. Mar., 26, 463-478, 2000.

Rahav, E., Herut, B., Levi, A., Mulholland, M. R., and BermanFrank, I.: Springtime contribution of dinitrogen fixation to primary production across the Mediterranean Sea, Ocean Sci., 9, 489-498, doi:10.5194/os-9-489-2013, 2013.

Roether, W., Manca, B. B., Klein, B., Bregant, D., Georgopoulos, D., Beitzel, V., Kovacevic, V., and Luchetta, A.: Recent changes in eastern Mediterranean deep waters, Science, 271, 333-335, 1996.
Schneider, A., Tanhua, T., Körtzinger, A., and Wallace, D. W. R.: High anthropogenic carbon content in the eastern Mediterranean, J. Geophys. Res., 115, C12050, doi:10.1029/2010JC006171, 2010.

Schroeder, K., Ribotti, A., Borghini, M., Sorgente, R., Perilli, A., and Gasparini, G. P.: An extensive western Mediterranean deep water renewal between 2004 and 2006, Geophys. Res. Lett., 35, L18605, doi:10.1029/2008GL035146, 2008.

Stöven, T.: Ventilation processes of the Mediterranean Sea based on CFC-12 ad SF6 measurements, Diploma, Leibniz-Institut für Meereswissenschaften der Mathematischnaturwissenschaftlichen Fakultät, Christian-Albrecht-Universität zu Kiel, Kiel, 2011.

Swift, J.: A guide to submitting CTD/hydrographic/tracer data and associated documentation to the CLIVAR and carbon hydrographic data office, ver. 4/22/08, UCSD Scripps Institution of Oceanography, http://cchdo.ucsd.edu/WHP_Exchange_ Description.pdf, 19 pp., 2008.

Tanhua, T.: METEOR-Berichte $84 / 3$, Repeat hydrography in the Mediterranean Sea, Hamburg, 1-45, 2013.

Tanhua, T., Álvarez, M., and Mintrop, L.: Carbon Dioxide, Hydrographic, and Chemical Data Obtained During the R/V Meteor MT84_3 Mediterranean Sea Cruise (5-28 April 2011), Carbon Dioxide Information Analysis Center, Oak Ridge National Laboratory, US Department of Energy, Oak Ridge, Tennessee, 2012. 